\title{
Nephrotoxicity as a cause of acute kidney injury in children
}

\author{
Ludwig Patzer
}

Received: 15 August 2007 / Revised: 2 October 2007 / Accepted: 4 October 2007 / Published online: 29 January 2008

(C) IPNA 2007

\begin{abstract}
Many different drugs and agents may cause nephrotoxic acute kidney injury (AKI) in children. Predisposing factors such as age, pharmacogenetics, underlying disease, the dosage of the toxin, and concomitant medication determine and influence the severity of nephrotoxic insult. In childhood AKI, incidence, prevalence, and etiology are not well defined. Pediatric retrospective studies have reported incidences of AKI in pediatric intensive care units (PICU) of between $8 \%$ and $30 \%$. It is widely recognized that neonates have higher rates of AKI, especially following cardiac surgery, severe asphyxia, or premature birth. The only two prospective studies in children found incidence rates of $4.5 \%$ and $2.5 \%$ of AKI in children admitted to PICU, respectively. Nephrotoxic drugs account for about $16 \%$ of all AKIs most commonly associated with AKI in older children and adolescents. Nonsteroidal anti-inflammatory drugs (NSAIDs), antibiotics, amphotericin $\mathrm{B}$, antiviral agents, angiotensin-converting enzyme (ACE) inhibitors, calcineurin inhibitors, radiocontrast media, and cytostatics are the most important drugs to indicate AKI as significant risk factor in children. Direct pathophysiological mechanisms of nephrotoxicity include constriction of intrarenal vessels, acute tubular necrosis, acute interstitial nephritis, and-more infrequently-tubular obstruction. Furthermore, AKI may also be caused indirectly by rhabdomyolysis. Frequent therapeutic measures consist of avoiding dehydration and concomitant nephrotoxic medication, especially in children with preexisting impaired renal function.
\end{abstract}

L. Patzer $(\bowtie)$

Children's Hospital St. Elisabeth and St. Barbara,

Mauerstrasse 5,

06110 Halle/S., Germany

e-mail: 1.patzer@krankenhaus-halle-saale.de
Keywords Renal side effects

$\begin{array}{ll}\text { Abbreviations } \\ \text { AKI } & \text { acute kidney injury } \\ \text { BMT } & \text { bone marrow transplantation } \\ \text { COX } & \text { cyclooxygenase } \\ \text { CyA } & \text { cyclosporine A } \\ \text { GFR } & \text { glomerular filtration rate } \\ \text { HSCT } & \text { hematopoietic stem cell transplantation } \\ \text { MTX } & \text { methotrexate } \\ \text { NSAIDs } & \text { nonsteroidal anti-inflammatory drugs } \\ \text { PDA } & \text { patent ductus arteriosus } \\ \text { PICU } & \text { pediatric intensive care unit } \\ \text { RCT } & \text { randomized controlled trial }\end{array}$

\section{Introduction}

Many different drugs and agents are currently being taken into consideration as the causality of nephrotoxic acute kidney injury (AKI) in children. Predisposing factors such as age, pharmacogenetics, underlying disease, dosage of the toxin, and concomitant medication determine and influence the severity of nephrotoxic insult. The culprit toxins are predominantly drugs, but exogenous (ethylene glycol, methylene) and endogenous (hemoglobin, myoglobin) substances and toxins from animals play a role as well. Throughout this teaching article, incidence, pathophysiological mechanisms, and treatment options are discussed in general followed by characteristics of problematic drugs. Because of the paucity of multicenter studies exploring AKI in children, previously conceived literature of AKI in adults ought to be considered. 
Tumor lysis syndrome is not discussed. However, calcineurin inhibitor toxicity is briefly mentioned, as it has been respectively inclusive to the topic throughout multiple publications [1-8].

\section{Definition and incidence}

Most authors define AKI as a sudden decline in glomerular filtration rate (GFR) mirrored by doublings of serum creatinine and azotemia. Because a precise clinical definition remains elusive, studies comparing epidemiology and outcome can be problematic (see Mehta et al. [9] for review). For oncological patients being treated with cytotoxic drugs, fractionated total body irradiation, and stem cell transplantation, AKI is due to multiple risk factors, with nephrotoxicity being one of the most significant. In this group of patients, a regimen-related toxicity score, as proposed by Bearman et al. [10], is often used. This score is defined as follows: grade 1-an increase in creatinine up to twice the baseline; grade 2 - an increase in creatinine above twice the baseline but not requiring dialysis; grade 3-renal replacement therapy required; grade 4-fatal toxicity.

In adults, the overall incidence of AKI was found to be 209 per million population $(0.02 \%)$. This figure was most likely generated by hypoxic/ischemic and nephrotoxic insults $[11,12]$. Other studies report incidence rates of between $7 \%$ and $25 \%$ among critically ill adults [13-16]. This broad range is partly due to the many different coexisting definitions of AKI currently used, as mentioned above.

Community-based statistics estimate the incidence of AKI attributed to drug nephrotoxicity as being between $0 \%$ and $7 \%[17,18]$ and the incidence of in-hospital AKI attributed to drug nephrotoxicity in adults at about $20 \%$ of all AKI [19-23]. Antibiotics (3-11\%), angiotensin-converting enzyme (ACE) inhibitors (0.5-7\%), NSAIDs (3-22\%), and contrast media $(2-12 \%)$ were noted as the most recurrent offenders. Depending on the publication date of the statistics, an increase in ACE inhibitors and a decrease in contrast media as causing agents was found during recent years (see de Broe et al. [24] for details). The trend in claiming higher frequencies of NSAIDs and ACE inhibitors as causes for drug-induced AKI was confirmed by a survey in 2001 by Ronco et al. [25]. It has been observed that hospital-acquired AKI is usually associated with one of three renal insults: a prerenal event, exposure to nephrotoxins, or sepsis [11]. Nephrotoxins, alone or in combination, contribute to at least $25 \%$ of all cases of hospital-acquired AKI [26]. In patients treated for oncological diseases, AKI was found to be between $0 \%$ and $40 \%$, depending on the cytotoxic regimen used [10, 27-35].

In childhood AKI, incidence, prevalence, and etiology are not well defined. Pediatric retrospective studies have reported incidences of AKI in pediatric intensive care units (PICU) of between $8 \%$ and $30 \%$ [36-39]. It is widely recognized that neonates have higher rates of AKI, especially following cardiac surgery, severe asphyxia, or premature birth [37, 40-44]. The only two prospective studies in children admitted to PICU found AKI incidence rates of $4.5 \%$ and $2.5 \%$, respectively $[45,46]$. In the study of Bailey et al. [45] (excluding neonates), the most common admission diagnoses in AKI were hemolytic uremic syndrome (18.2\%), oncologic pathologies (18.2\%), and cardiac surgery (11.4\%). Although these authors could demonstrate by univariate analysis that nephrotoxic drugs were used more often in children with AKI, they could not indicate nephrotoxic drugs as a risk factor for AKI by multivariate analysis. A 2005 report from Houston, Texas, USA, stated the most common causes of AKI in hospitalized children were renal ischemia (21\%), pharmacologic agents $(16 \%)$, and sepsis (11\%). Primary renal disease accounted for only $7 \%$ of all cases [38]. Furthermore, this study associated nephrotoxic medications with AKI in primarily older children and adolescents. The frequency of AKI in pediatric patients following hematopoietic stem cell transplantation (HSCT) is between $6 \%$ and $50 \%$, of whom $5-10 \%$ require renal replacement therapy [47-50].

\section{Drug-induced AKI: mechanisms and clinical significance}

Table 1 illustrates a classification of drugs known to cause AKI regarding pathophysiologic mechanisms (from Porter et al. in [24]). The following text reviews in more depth the aspects of the most common substances at risk for causing AKI in children.

\section{NSAIDs}

NSAIDs possess antipyretic, analgesic, and anti-inflammatory effects. They are frequently used in children and have numerous therapeutic indications; for example, in the treatment of fever, postoperative pain, and inflammatory disorders such as juvenile idiopathic arthritis and Kawasaki disease. Their major mechanism of action is through inhibition of prostaglandin biosynthesis by blockade of cyclooxygenase (COX). In euvolemic states, prostaglandins have a negligible effect on renal hemodynamics. In states of volume depletion, there is upregulation of the reninangiotensin system as well as increased catecholamine 
Table 1 Classification of various drugs based on pathophysiologic categories of acute kidney injury

\begin{tabular}{|c|c|}
\hline Pathophysiology & Drugs known to cause acute kidney injury \\
\hline Prerenal failure & $\begin{array}{l}\text { NSAIDs, ACE inhibitors, cyclosporine A } \\
\text { (CyA), norepinephrine, AT2-receptor } \\
\text { antagonists, diuretics, interleukins, cocaine, } \\
\text { mitomycin C, tacrolimus, estrogen, quinine }\end{array}$ \\
\hline $\begin{array}{l}\text { Acute tubular } \\
\text { necrosis }\end{array}$ & $\begin{array}{l}\text { Antibiotics: aminoglycosides, cephalosporins, } \\
\text { amphotericin B, rifampicin, vancomycin, } \\
\text { foscarnet, pentamidine } \\
\text { NSAIDs, glaphenin, contrast media, } \\
\text { acetaminophen, CyA, cisplatinum, i.v. } \\
\text { immunoglobulin, dextran, maltose, sucrose, } \\
\text { mannitol, heavy metals }\end{array}$ \\
\hline $\begin{array}{l}\text { Acute interstitial } \\
\text { nephritis }\end{array}$ & $\begin{array}{l}\text { Antibiotics: ciprofloxacin, methicillin, } \\
\text { penicillin G, ampicillin, cephalosporins, } \\
\text { oxacillin, rifampicin } \\
\text { NSAIDs, glaphenin, acetylsalicylic acid } \\
\text { (ASA), fenoprofen, naproxen, } \\
\text { phenylbutazone, piroxicam, tolmetin, } \\
\text { zomepirac, contrast media, sulfonamides, } \\
\text { thiazides, phenytoin, furosemide, allopurinol, } \\
\text { cimetidine, omeprazole, phenindione }\end{array}$ \\
\hline Tubular obstruction & $\begin{array}{l}\text { Sulfonamides, methotrexate, methoxyflurane, } \\
\text { glaphenin, triamterene, acyclovir, ethylene } \\
\text { glycol, protease inhibitors }\end{array}$ \\
\hline $\begin{array}{l}\text { Hypersensitivity } \\
\text { angiitis }\end{array}$ & Penicillin G, ampicillin, sulfonamides \\
\hline $\begin{array}{l}\text { Thrombotic } \\
\text { microangiopathy }\end{array}$ & Mitomycin C, CyA, oral contraceptives \\
\hline
\end{tabular}

From reference [24]

release that, in addition to producing renal vasoconstriction, stimulates renal prostaglandin production. These prostaglandins counteract the vasoconstrictor effect by decreasing preglomerular resistance and thereby maintaining renal perfusion and glomerular filtration. This protective effect is inhibited by the blockade of prostaglandin synthesis by NSAIDs. The disposition of most NSAIDs has been mainly studied in infants older than 2 years of age [51]. Next to paracetamol, it is likely that NSAIDs are the most often prescribed substances in pediatrics today.

Although AKI is a well-known adverse effect of these drugs, the incidence of nephrotoxicity due to NSAIDs, especially in children, is unknown. It is probable that these substances carry a good risk-benefit ratio when taken under adequate supervision. However, when taken continually by the elderly or individuals with comorbid conditions (dehydrated children), the frequency of adverse reaction rises dramatically.

The vast majority of healthy children who ingest therapeutic doses of NSAIDs for a limited duration tolerate them without any significant adverse effects. However, the risk of renal toxicity potentially increases in situations where there is stimulation of the renin-angiotensin system; for example, with volume depletion or preexisting chronic renal disease. Some case reports of AKI following NSAID administration have been published. In most of these cases, dehydration played an important role [52-54]. But even without concomitant treatment or dehydration, AKI following the intake of naproxen, diclofenac, ibuprofen, dipyrone, ketorolac, and paracetamol has become documented and published $[55,56]$. The onset of AKI after the intake of medication ranged from 1 to 5 days. Oligo-/anuric and nonoliguric AKI has been documented and published. Ultrasound showed large kidneys with hyperechoic parenchyma, and urine analysis revealed no specific changes that would allow distinction from other causes of AKI. Though kidney biopsies in two out of three patients showed normal results, one out of three revealed interstitial inflammation. All documented patients showed good recovery of renal function. Also, AKI in three children treated with the COX-2 inhibitor rofecoxib has been recently published. Evidently, all children were managed without renal replacement therapy. However, a renal biopsy done in one child showed acute interstitial nephritis [57]. The COX-2 inhibitor celecoxib has been reportedly responsible for $24 \%$ of adult AKI $[58,59]$.

In neonates the therapeutic and/or preventive use of ibuprofen and indomethacin for closure of patent ductus arteriosus (PDA) in preterm and/or low birth weight infants was analyzed in a Cochrane review. It showed that ibuprofen reduced the risk of oliguria. It also demonstrated that a prolonged course of indomethacin was associated with a decreased incidence of renal function impairment, as evidenced by a lower proportion of infants having diminished urine output [60-62]. Currently, several cases of severe and sometimes irreversible renal insufficiency have been documented in neonates exposed to indomethacin prenatally or in the first days of life for treatment of PDA [63, 64].

In adults treated with Mesalazine because of inflammatory bowel disease, nephrotoxicity is reportedly evident in the treatment of one out of every 150 adult patients. Although more than 30 cases in adults have been described in the literature, only three cases of pediatric patients younger than 16 years have been published (see Biervliet et al. [65] for details). There is no relation to dosage or type of Mesalazine used; the underlying mechanism was interstitial nephritis leading to acute or chronic renal failure.

In summary, NSAIDs- and COX-2-inhibitor-induced renal failure in children is rare. However, if found, it is usually reversible after drug discontinuation. Caution should be taken when NSAIDs are administered to individuals with dehydration, preexisting renal problems, or in combination with other potentially nephrotoxic drugs. 
Antibiotics, amphotericin $\mathrm{B}$, and antiviral agents

\section{Aminoglycosides and vancomycin}

Nephrotoxicity is a well known side effect of all aminoglycosides. Acute tubular necrosis is the most frequent mechanism of toxicity, but different patterns of tubular dysfunction have been described as well [66]. Aminoglycosides are not metabolized and eliminated by glomerular filtration and are partially absorbed into proximal tubular cells by megalin-dependent endocytosis. This uptake is saturable. In the lysosomes, aminoglycosides bind to phospholipids, leading to inhibition of phospholipase activity and consequently to phospholipid accumulation within the proximal tubular cell. Although the exact mechanism of tubular cell death caused by phospholipid accumulation has never been clearly established, there is a good correlation between the extent of phospholipidosis and toxicity induced by aminoglycosides. Furthermore, aminoglycosides induce alterations at the basolateral membrane and mitochondria, and they seem to enhance the generation of free radicals and lipid peroxidation in renal cortex. They also may alter glomerular function through mesangial cell contraction and may stimulate mesangial cell proliferation and apoptosis with no overt net change in total cell number [67].

Thirty years ago, the incidence of significant reduction of GFR present in seriously ill adult patients was found to be between $5 \%$ and $9 \%[68]$ and to rise with advanced age [69-71]. Neonates are at higher risk for aminoglycosideinduced nephrotoxicity. It is published that drug dosage, timing, duration of administration, dosing interval, preexisting renal disease, volume depletion, hepatic dysfunction, sepsis, and concomitant nephrotoxic and diuretic drugs may increase nephrotoxicity of aminoglycosides, but some of the published data are conflicting [24, 72]. It is especially not clear whether dosing only once daily decreases the risk of nephrotoxicity. This question was addressed in children by Uijtendaal et al. [73] in a randomized controlled trial (RCT) that found equal effectiveness and nephrotoxicity of gentamicin. In contrast in a meta-analysis of children with cystic fibrosis, Smyth et al. [74] found decreased toxicity in once-a-day treatment. As published by Verpooten et al., neither monitoring drug serum peak levels nor adjusting dosage (pharmacokinetic dosing) had any effect on nephrotoxicity [75].

A recent Cochrane analysis by Rao et al. [76] found that in neonates, there is insufficient evidence from available RCTs to conclude whether a regimen of once a day or multiple doses a day of gentamicin is superior in treating proven neonatal sepsis. However, data suggests that pharmacokinetic properties of a once-a-day regimen are superior to multiple doses a day because it achieves higher peak levels while avoiding toxic trough levels without change in nephrotoxicity or auditory toxicity.

Beta ( $\beta$ )-lactam antibiotics comprise penicillins, cephalosporins, monobactams, clavulanic acid, and carbapenems. Cephalosporins and carbapenems have been associated with nephrotoxicity in humans $[77,78]$. Nephrotoxic $\beta$-lactam antibiotics cause acute proximal tubular necrosis with or without oliguria. Significant renal toxicity, which has been rare with penicillins and uncommon with cephalosporins, is a greater risk with the penems. The true incidence of $\beta$ lactam-antibiotics-induced AKI is unknown, as is how often it occurs when the antibiotic is used as monotherapy or in combination with other nephrotoxic drugs. Mechanisms of injury include: (1) transport into the tubular cell (mainly through the basolateral organic anion secretory carrier), (2) acylation of target proteins causing respiratory toxicity by inactivation of mitochondrial anionic substrate carriers, and (3) lipid peroxidation [77]. Renal toxicity from $\beta$-lactams may also result from hypersensitivity reactions. In these cases, glucocorticoids have been used, as they may improve recovery [79]. Cases of ceftriaxone-induced hemolysis and nephrolithiasis complicated by AKI have also been published [80-82]. In preterm neonates, the administration of ceftazidime was associated with a greater risk of acute kidney injury [83]. Ampicillin and aztreonam combination therapy in neonates showed a lower renal toxicity than in the group with concurrent administration of oxacillin and amikacin [84]. There are no specific therapeutic options in $\beta$-lactam-induced AKI; hemolysis and postrenal failure by stones need to be excluded, and there is no evidence that hemodialysis will improve recovery. "Judicious use of the drugs" [85] has become the most important approach to decreasing $\beta$-lactam nephrotoxicity, especially in neonates, where accurate determination of dosage is required for drugs with low therapeutic index and in patients with renal injury.

Macrolide antibiotics such as erythromycin, clarithromycin, azithromycin, and dirithromycin may indirectly cause AKI via enhancing calcineurin levels by inhibiting cytochrome P-450 isoenzyme CYP 3A4 [86]. This needs to be considered, especially in transplanted or nephrotic patients on CyA or tacrolimus.

A number of additional anti-infective drugs that may cause AKI in children include sulfonamides, trimethoprimsulfamethoxazole (TMP-SMX) and quinolones. Some of these are of interest because of their use in treating infectious complications in patients with HIV infections. Systematic evaluation of renal side effects of these substances in children are lacking, though aspects of nephrotoxicity in adults are discussed in detail by Vaamonde et al. [87].

Nephrotoxicity of amphotericin B has been a matter of research for a long time. Despite its significant renal side 
effects, amphotericin B is still the drug of choice in the treatment of severe systemic fungal infections, especially in immunocompromised children. Its nephrotoxicity and measures of prevention have been recently reviewed by Koren and coworkers [88, 89] and Fanos et al. [90], but studies in children remain scarce. In retrospective studies, nephrotoxicity was found in $20-80 \%$ of adults and children [91-95]. Of transplant patients receiving amphotericin B, AKI was found to be in $0.5 \%$ of heart and/or lung transplants and $31 \%$ of bone marrow transplants [96]. The two major hypotheses for the pathogenesis of amphotericinB-induced AKI are: (1) direct effects of the drug on ergosterol in the epithelial cell membranes and (2) renal vasoconstriction due to increased vascular resistance. Typically, intravenous administration results in an acute decrease of GFR and transient oliguria followed by polyuria. Unlike most other drug-induced nephrotoxicity, most patients develop distal tubulopathy as well. The pharmacokinetics of amphotericin B in children appears to differ from that in adults because distribution volume is smaller and the clearance rate is faster. As elimination halflife appears to be inversely correlated with a patient's age, individualized dosing based on drug monitoring has been recommended. But the age-dependent nephrotoxicity of amphotericin B has not yet been addressed by studies. Risk factors for amphotericin-induced AKI include cumulative dose, treatment duration and dosing schedule, concomitant therapy with diuretics or other nephrotoxic drugs, and impaired GFR at baseline. As shown by a number of RCTs in adults, the introduction of the lipid formulation of the drug (lipid complex, colloidal dispersion, and liposomal form) decreased nephrotoxicity enormously [97]. Goldman et al. [88] proposed guidelines for preventing amphotericininduced nephrotoxicity by suggesting a saline infusion prior to administration (10-15 ml/kg body weight) and use of lipid formulations of amphotericin B in children with either known side effects to conventional amphotericin $\mathrm{B}$, reduced GFR, or concomitant nephrotoxic medication.

Antiviral agents (acyclovir, valacyclovir, ganciclovir, cidofovir, foscarnet, amantadine, and ribavirin) have become increasingly available for clinical use, especially to treat HIV infections. AKI is a significant and potentially therapy-limiting side effect to some of them. Antiviral agents have also been known to cause irreversible renal damage in adults [98]. Antiviral drugs cause renal failure through a variety of mechanisms. Direct renal tubular toxicity has been found in the use of a number of these medications, with unique effects on kidney epithelial cells. These drugs include cidofovir, adefovir dipivoxil, tenofovir, and acyclovir. Additionally, crystal deposition in the kidneys may promote development of renal failure, as in the use of acyclovir and the protease inhibitor indinavir. However, it is unclear whether the pathogenesis of acyclovir-induced AKI reflects an obstructive uropathy from intratubular precipitation of acyclovir, a hemodynamic response, or an immunologic, toxic, or hypersensitivity reaction. Furthermore, these substances effect the tubular transporters as well as tubule cells directly [99]. The exact frequency of nephrotoxicity induced by antiviral drugs is difficult to determine and not exactly known. AKI by acyclovir infusion was found to be between $10 \%$ and $16 \%$ in adults and $11 \%$ in children [100]. A recent Brazilian study found AKI in $19.5 \%$ of the 41 children treated intravenously. Their creatinine levels peaked in a mean time of 7.1 days (ranging from 3 to 14 days). Recovery of renal function, evaluated by the decrease of creatinine levels, varied from 1 to 7 days (mean 3.6 days) [101]. Vomiero et al. [102] reported AKI in three out of 17 children treated with ceftriaxone and acyclovir combination therapy because of meningoencephalitis pointing out that the addition of a second nephrotoxic drug aggravated the extent of acyclovir's renal injury. Risk factors again include volume contraction, preexisting renal insufficiency, high dose, or rapid bolus infusion. AKI in children caused by valacyclovir and ganciclovir has not been published.

Foscarnet causes a reversible decrease in GFR in 20 $60 \%$ in adults [103-106]. Two mechanisms for renal damage have been reported: acute tubular necrosis and crystallization within glomerular capillaries with crescentic nephritis. Hydration at the time of administration is thought to reduce the incidence of AKI [72]. Foscarnet-induced AKI is usually reversible, though temporary dialysis may be required. Volume expansion was once again effective in reducing the incidence of foscarnet nephrotoxicity [107]. In an RCT by Reusser et al. [108] of foscarnet vs. ganciclovir in the preemptive therapy of cytomegalovirus infection after allogeneic stem cell transplantation, renal function impairment was observed in five (5\%) patients on foscarnet vs. two $(2 \%)$ patients on ganciclovir.

Published data regarding renal failure in antiretroviral agents is scarce, especially in children. Some patients have been reported with AKI attributed to ritonavir, but the risk of AKI in this group of drugs appears low.

\section{ACE inhibitors and angiotensin II receptor type 1 antagonists}

The use of ACE inhibitors and angiotensin II receptor type 1 antagonists (AT2-receptor antagonists) has increased dramatically over the last decade [109-115]. ACE inhibitors are the best documented treatment for delaying progression of chronic nondiabetic renal diseases and nephropathy in patients with type 1 diabetes. However, some major concerns appear to restrict the widespread use of these drugs, including acute interstitial nephritis associated with ACE inhibitors and a fall of GFR in some risk 
groups $[116,117]$. In this educative article, we briefly mention some aspects of AKI and ACE inhibitors and refer to some reviews about ACE inhibition in adults and children [114, 118].

The presence of AKI due to ACE-inhibitor-induced interstitial nephritis has been described in few adult cases, but an occurrence of this kind in children has yet to be documented [119]. In contrast, however, prerenal AKI in children with nephrotic syndrome, impaired renal function, hypertension, congestive heart failure, or postrenal transplant patients treated with ACE inhibitors alone or in combination with AT2-receptor antagonists are well known in pediatric renal (and cardiac) clinics and have been reported [116, 117, 120-122].

It is generally accepted to be true, though not exactly proven, that the renal hemodynamic effects of ACE inhibitors are due to the blockade of a renin-angiotensin system. In a significant percentage of renal patients (renal artery stenosis, end-stage renal disease) and in patients with congestive heart failure, especially when volume depleted (diuretics, nephrotic syndrome), the maintenance of GFR is highly dependent on angiotensin-II-mediated efferent vasoconstriction. In the case of instituting ACE inhibitors and/or AT2-receptor antagonist treatment, close surveillance of renal function and blood pressure is needed, at least during the first 2 weeks, because a decline in renal function may be transient. The treatment should be started at low doses then gradually increased. The concomitant use of NSAIDs should be avoided, because in these situations, the afferent vasoconstriction (by prostaglandin synthesis inhibition) in combination with efferent vasodilatation (due to ACE inhibition) may result in a marked decline of GFR. The sometimes inevitable combination of ACE inhibitors and calcineurin inhibitors needs close monitoring and expertise.

AKI has not been seen after the administration of other antihypertensive agents that do not interfere with the reninangiotensin system.

\section{Calcineurin inhibitors}

The therapeutic potential and renal side effects of CyA and tacrolimus are well known to pediatric nephrologists. The introduction of calcineurin inhibitors has improved the outcome of renal and other organ transplants dramatically, but cyclosporine-related nephrotoxicity has become a significant side effect to manage [8]. Indeed, nephrotoxicity is the most significant and limiting adverse effect caused by calcineurin inhibitors. This paper only discusses aspects of AKI related to calcineurin inhibitors. Acute nephrotoxicity is a hemodynamically mediated phenomenon characterized by the absence of permanent structural changes and reversibility with decrease or discontinuation of the offending or concomitant nephrotoxic (interacting) drug [123].

GFR impairment is caused by intrarenal vasoconstriction that induces a decrease in renal blood flow. A great deal of effort has been taken to unravel the mechanism of CyAinduced vasoconstriction. Some mechanisms and mediators have been found. The renin-angiotensin-aldosterone system is involved [124], as are endothelin (a very potent constrictor of intrarenal vessels), nitric oxide, prostaglandins, free radicals, sympathetic system, vasopressin, atrial natriuretic factor(s), and some further substances [123]. The clinical presentation of acute CyA toxicity may present as $\mathrm{AKI}$, asymptomatic increase of serum creatinine, hemolytic uremic syndrome (HUS), or a delayed recovery of renal graft function after renal transplantation. The exact incidence of these forms are unknown. The most frequent is an asymptomatic increase of serum creatinine. Clinically relevant AKI is published in $10 \%$ to more than $50 \%$ of all patients in the early phase after nonrenal transplantation [125-129]. The exact incidence in the pediatric population is unknown, because AKI in these patients is generally multifactorial and seldom related exclusively to CyA.

Especially in renal transplant patients, nephrotoxicity caused by calcineurin inhibitors may be difficult to distinguish from transplant rejection. In this situation, a renal biopsy may be indicated. Otherwise, in extrarenal organ transplantation and nonrenal autoimmune disease patients, a creatinine rise is very likely to be caused by CyA. As mentioned above, interaction of concomitant drugs enhancing CyA levels via inhibition of cytochrome P450 system (especially macrolide antibiotics, calcium channel antagonists, and antifungal azoles) needs to be considered, as this combination can cause AKI. Drugs that decrease renal blood flow should also be avoided whenever possible. Especially in bone marrow transplantation (BMT), CyA can cause acute HUS, usually with severe AKI, carrying a poor prognosis.

The acute nephrotoxicity profile of tacrolimus is very similar to that of CyA, as it induces reversible functional changes with the same frequency and intensity [123]. There are still no satisfactory strategies and measures to prevent CyA- and tacrolimus-induced AKI in children. Studies on omega-3 fatty acids, cilastatin, and endothelin receptor antagonists have been published with clinically positive results in preventing GFR impairment, but none of them are used routinely in clinical practice. One would recommend regular monitoring of blood levels, caution with concomitant medication, and avoidance of dehydration. Nevertheless, despite all these measures, CyA and tacrolimus still carry a significant risk of acute nephrotoxicity in patients who suffer from severe diseases. New substances will probably allow protocols without calcineurin inhibitors, 
minimizing the risk of drug toxicity and improving allograft and patient survival [130].

\section{Radiocontrast media}

The incidence of AKI after administration of tri-iodinated radiocontrast media has been found to be between $1 \%$ and $20 \%$ in adults [131]. Incidence in children is unknown. As the new nonionic contrast media are less nephrotoxic, one would assume that the frequency of AKI related to contrast media has dropped over the last decade, but this is counterbalanced by an increase in the use of radiographic contrast investigations in an older age group. Furthermore, nonionic contrast media were found without any benefit in patients with normal renal function $[132,133]$.

Radiographic contrast-agent-induced nephropathy is caused by vasoconstriction-mediated renal medullary ischemia and direct toxic damage to renal tubular epithelial cells. These effects may be partially mediated by the generation of reactive oxygen species. Most cases present as nonoliguric AKI, although oliguric renal failure is possible as well [72]. Maximum creatinine rise usually occurs 3-5 days after admission of contrast media. Urine analysis often reveals granular casts, tubular epithelial cells, and minimal proteinuria but may be entirely unremarkable in some cases. Usually, the fractional excretion of sodium is very low. Risk factors include baseline impairment of renal function, diabetes mellitus, congestive heart failure, higher doses of contrast media, and concurrent use of nephrotoxic drugs. Of all these risk factors, preexisting renal function impairment appears to be the single most important. Preventive measures include intravenous hydration and administration of acetylcysteine [134-136]. However, the administration of calcium antagonists, theophylline, atrial natriuretic peptide, mannitol, furosemide, and dopamine has not shown to be effective [137]. In adults, dialysis is infrequently required, and some degree of residual renal impairment has been reported in about $30 \%$ of affected adults.

\section{Cytostatics}

Nephrotoxicity related to cytotoxic treatment in children with oncological diseases is well known and has been reviewed several times [27, 138-145]. Ifosfamide causes predominantly chronic tubulopathy, sometimes beginning months or years after therapy. AKI has seldom been reported. In a study by Skinner et al. [141], impairment of GFR was observed in 61 of 123 patients, but overt renal failure was not found. However, in studies by Rossi et al., no acute renal failure has been reported [146-147]. Higher total ifosfamide dosage correlated significantly with greater glomerular toxicity. In adults, AKI related to ifosfamide has been documented secondary to tubular necrosis with highdose therapy $\left(>5 \mathrm{~g} / \mathrm{m}^{2}\right)$, particularly in patients concurrently treated with cisplatin [148, 149]. In children, AKI case reports of prerenal failure due to water and sodium loss caused by the tubulopathy have been published [150].

Cisplatin may induce both acute and chronic renal toxicity [151]. A progressive and persistent reduction in GFR may follow each successive treatment cycle. The precise mechanisms involved in cisplatin-induced renal failure have not been completely clarified, but mitochondrial dysfunction and apoptosis are likely to play an important role. Inflammatory mechanisms may contribute to toxin-induced acute kidney injury as well $[152,153]$. Early clinical studies with cisplatin reported dose-related AKI in more than $70 \%$ of adult patients [154]. In a series of 22 children receiving cisplatin, Womer et al. described a GFR of less than $80 \mathrm{ml} / \mathrm{min}$ per $1.73 \mathrm{~m}^{2}$ in 18 patients [155]. Polyuria regularly follows administration of cisplatin and occurs in two distinct phases. The first is within the first $24-48 \mathrm{~h}$ after administration, urine osmolality drops but GFR remains stable. This stage of early polyuria usually reverses spontaneously. The second phase of polyuria is $72-96 \mathrm{~h}$ after cisplatin administration and is characterized by an increase in urine volume and a persistent reduction in the GFR [156]. In efforts to reduce renal toxicity associated with cisplatin, therapeutic interventions have been aimed at the reduced production and enhanced excretion of highly reactive metabolites. Infusion of mannitol and saline is the clinical intervention most commonly used. The effectiveness of these measures is somewhat illustrated by a randomized study in adults by $\mathrm{Al}$ Sarraf et al. [157], but this protective effect was lost during subsequent cycles. The use of hypertonic (3\%) saline infusion as an effective renoprotective measure awaits a randomized study as well, but cisplatin should not be given to volume-depleted patients. Another potential angle is to take a patient's GFR into account in dosing. This has already been proposed by some therapeutic protocols. Also with cisplatin, the concurrent administration of NSAIDs, aminoglycosides, or other nephrotoxic drugs should be avoided.

Recently, a liposomal formulation of cisplatin, Lipoplatin, was developed to reduce systemic toxicity of cisplatin. It is under clinical evaluation in adult medicine, and phase 1 and phase 2 studies showed no nephrotoxicity up to a dose of $125 \mathrm{mg} / \mathrm{m}^{2}$ every 14 days [158, 159]. However, data on effectiveness and toxicity in pediatric oncology are not yet available.

Acute kidney injury has also been reported following administration of high-dose methotrexate (MTX). The most commonly accepted mechanism for this drug-induced 
toxicity is the precipitation of MTX and its metabolites in the distal tubules, leading to obstructive uropathy and tubular necrosis. Urinary alkalization and hydration offer protection against MTX-induced renal dysfunction. In patients with MTX-induced AKI, charcoal hemoperfusion and sequential hemodialysis with high-flux dialyzers were able to achieve a significant clearance of MTX. More recently, carboxypeptidase-G(2) [CPDG(2)] (a recombinant bacterial enzyme that rapidly hydrolyzes MTX to inactive metabolites) has become available in the treatment of MTX-induced renal dysfunction. CPDG(2) administration has been well tolerated and results in consistent and rapid reductions in plasma MTX concentrations by a median of 98.7\%. Early administration of $\operatorname{CPDG}(2)$ in combination with leucovorin may be beneficial for patients with MTXinduced renal dysfunction and significantly elevated plasma MTX concentrations [160].

The combination of nephrotoxic drugs in the setting of HSCT intensifies nephrotoxic probability. Renal aspects of this specific therapeutic maneuver have been reviewed elsewhere [138], so here we summarize the important aspects of AKI in this very specific group of patients. Incidence of AKI immediately after HSCT in pediatric patients appears to be between $25 \%$ and $50 \%$ [161], with 5$10 \%$ requiring renal replacement therapy. In a prospective study involving 89 children, AKI was found in $25 \%$ within 30 days after HSCT. Specific renal syndromes appear in the course of HSCT at different time intervals, revealing a similar pattern in children in comparison with adult patients [27, 162]. In both children and adults, impaired renal function associated with liver impairment (hepatorenal syndrome) is the most significant cause of AKI. Further causes for AKI in the early phases after HSCT are septicemia, hypotension, drug toxicity, and the use of amphotericin B. To assess AKI risk factors in our pediatric population, we carried out logistic regression analyses and found allogeneic HSCT, conditioning containing cyclophosphamide, and etoposide, septicemia, hyperbilirubinemia, venoocclusive disease, and the use of spironolactone significantly correlated with AKI. However, age, diagnosis, and TBI did not. Specific therapeutic approaches have not yet been known to lower frequency or to improve outcome so far.

A growing number of case reports have been published in adult medicine regarding the nephrotoxicity of bisphosphonates. With regard to zoledronate, the incidence of AKI has been found to be between $9 \%$ and $13 \%$. The pathology showed diffuse tubular atrophy and injury without interstitial nephritis. Bisphosphonate-induced AKI in children remains undocumented [163, 164].

Whereas therapy with intravenous immunoglobulin has been known to carry a $1-15 \%$ risk of AKI in adults [165-
167], only a few case reports in children have been published [168]. Presumable risk factors consist of an impaired GFR and age over 65 years.

\section{Natural toxins}

Toxin-induced AKI by prescription of herbal and alternative medicines is uncommon in Europe but has become a common cause of mortality and morbidity in Africa (see Swanepoel et al. for review [169] and [170]). Animal nephrotoxin-induced AKI is also uncommon in Europe but well known to colleagues from Africa, South America, and Australia. Table 2 outlines a list of common biologic nephrotoxins produced by animals. Many of these toxins cause AKI by direct or indirect mechanisms. The main indirect mechanism is rhabdomyolysis [171]. Some direct mechanisms include acute tubular necrosis, acute interstitial nephritis, necrotizing arteritis, and sometimes extracapillary glomerulonephritis. The consumption of a raw fish gallbladder containing toxic ichthyogallotoxin has been known to cause AKI in children and has been reported. In this instance, therapeutical approaches are symptomatic, and sometimes, intensive care and renal replacement therapy may be required.

\section{Diagnosis, treatment, and outcome}

Clinical management and supportive therapy of children with suspected or established AKI caused by nephrotoxicity is not unlike other forms. A child's clinical history may help reveal which drugs had been administered within the previous 5-7 days. Postrenal obstruction needs to be excluded by ultrasound, and infective or immunological causes need to be addressed by laboratory investigations. Hemolysis and rhabdomyolysis need to be excluded, especially in cases of dark urine (which is sometimes misinterpreted as macrohematuria).

Table 2 Common biologic nephrotoxins produced by animals. Modified from Chesney and Jones [72]

\begin{tabular}{ll}
\hline Animal & Biologic nephrotoxins \\
\hline Snake & $\begin{array}{c}\text { Phospholipase } \mathrm{A}_{2} \text {, myotoxins, } \\
\text { procoagulant-activating factors } \\
\end{array}$ \\
V and X \\
Sphingomyelinase D, neurotoxins \\
Bee & Melittin, phospholipase $\mathrm{A}_{2}$, mast-cell \\
& degranulation protein \\
Wasp & Antigen 5, mastoparans \\
Murine animals (carp, & Ichthyogallotoxin, cyprinol \\
jellyfish, sea anemone) & \\
\hline
\end{tabular}


It is of great importance to assess the exact status of hydration (fractional excretion of sodium, urine sodium, urine osmolality) and to decide whether a load of fluid or diuretics may be necessary. Correction of volume depletion and/or congestive heart failure and reversing diminished renal perfusion are of primary importance. Especially in patients with dehydration, special attention has to be paid to good fluid management and replacement to establish adequate renal blood flow and perfusion. The administration of renal-dose dopamine (1-3 $\mu \mathrm{g} / \mathrm{kg} \min$ ) was shown to be ineffective on patient survival or outcome in both adults [172-174] and children [175]. There is no evidence from randomized trials to support the use of dopamine to prevent renal dysfunction in indomethacin-treated preterm infants [176].

Diuretics have also been used in patients with oliguric AKI to improve urine output, which may decrease the concentration of toxins and improve clearance of solute and medications. It should be noted, however, that the increase in urine flow provided by diuretic therapy does not reflect an improvement in GFR, nor has it been demonstrated to prevent or facilitate recovery from acute tubular necrosis [177]. In addition, children with AKI may deteriorate further with diuresis, particularly patients with prerenal or radiocontrast-induced AKI [178].

As children with nephrotoxic insults are more likely to suffer nonoliguric renal failure, serum chemistry needs to be supervised very carefully in high-risk children. It has also to be considered that in children with reduced muscle mass (oncological diseases), GFR is overestimated by assessment of serum creatinine (or Schwartz formula). These two aspects may delay the diagnosis of AKI or may result in GFR overestimation. When medications are prescribed in AKI, the mechanism of drug elimination, metabolic pathway, and possible further nephrotoxic effects must be considered and adjustments made for the degree of renal failure.

In case of suspected or definite nephrotoxic agents being the cause of AKI, drug withdrawal is the most important measure physicians can take, as avoidance of further possible nephrotoxic agents needs to be strictly considered. In all children, the basic principles of managing AKI are fluid maintenance, electrolyte homeostasis, and adequate nutrition. Only few patients will require specific treatment as acetylcysteine in radiocontrast nephropathy. In interstitial nephritis, corticosteroids may be given, but their benefits are not proven by RCTs.

Regarding indication and optimal choice of renal replacement therapies, we refer to published reviews and guidelines [179-184].

The mortality of children with AKI was found to be between $8 \%$ and $89 \%$ in retrospective studies $[39,40]$. In prospective studies, Bailey et al. report a mortality rate of
$29.6 \%$ in patients with AKI compared with $2.3 \%$ in patients without [45], and the Spanish study found a mortality rate of $36 \%$ in patients with AKI [46]. Recent data from Houston showed a 3 - to 5-year survival rate of $79.9 \%$ of children with AKI who survived to hospital discharge [185]. Most deaths (68.5\%) occurred within 12 months after initial hospitalization. Combining those who died during initial hospitalization and in the subsequent 35 years, the overall survival rate was 56.8\% [185]. Renal survival in survivors was 91\%. Among 29 patients assessed at 3-5 years, 59\% had at least one sign of renal injury (microalbuminuria, a decreased GFR, hyperfiltration, or hypertension). In that study, AKI was caused by nephrotoxic agents in $14.3 \%$. With regard to the fate of individuals who develop AKI caused by nephrotoxicity, several outcomes have been reported in adults. In most cases, the drug's nephrotoxicity is partly or wholly reversible. However, some authors have suggested that as many as $50-60 \%$ of adults who suffer nephrotoxicity may retain an element of permanent renal damage [186, 187].

In the setting of HSCT, the doubling of serum creatinine is associated with a twofold increase in mortality in adults, and the need for dialysis predicts a mortality rate of 80 $90 \%$ [30, 188]. In comparison with adults, AKI and renal replacement therapy were also associated with an increase in mortality [47, 50, 189]. On the other hand, the predictive value of transient AKI for renal function in long-term survivors remains controversial. In some studies, renal impairment during the early phase of HSCT was not predictive of later renal impairment [48, 190], whereas Kist-van Holthe et al. found correlations between high serum creatinine within 3 months after BMT and chronic renal failure 1 year after BMT [49] but only a weak predictive value of acute AKI for chronic renal failure [191].

\section{Conclusion}

The true incidence of nephrotoxicity as a cause of AKI in children is unknown. In general, drugs are an infrequent cause of community-acquired AKI, especially in children. However, drugs and hypoxia are the leading etiologic factors for hospital-acquired AKI, and it remains a significant cause of morbidity and mortality in children. Despite advances in understanding the pathophysiology of AKI, little progress has been made in its treatment. The judicious use of all nephrotoxic drugs and their combinations, together with adequate hydration, are still the most important measures to take in the minimization of nephrotoxicity. Children with AKI caused by nephrotoxic agents have a significant risk for chronic renal injury. 
Questions (answers appear following reference list)

1. Which one of the following statements is true of NSAIDs-induced AKI?

A In most children with NSAIDs-induced AKI, dehydration played an important role.

B NSAIDs-induced AKI is mostly caused by interstitial nephritis.

C Mesalazine-induced AKI is always caused by interstitial nephritis.

D Glucocorticoids play an important role in treatment of NSAIDs-induced AKI.

2. Which one of the following statements is true? Neonates:

A Have higher rates of nephrotoxicity-induced AKI compared with older children.

B Have generally a poor long-term prognosis in relation to nephrotoxicity-induced AKI.

C Benefit from a "pharmacological dosing" of gentamicin regarding nephrotoxicity.

D Benefit generally from ibuprofen compared with indomethacin regarding the closue of PDA.

3. Which one of the following answers is not true?

A $\beta$-lactam antibiotics need tubular transport for nephrotoxicity.

B Renal replacement therapy always shortens the time of renal insufficiency by removing toxins.

C Ceftriaxone may induce AKI indirectly by hemolysis and nephrolithiasis.

D Macrolide antibiotics may cause indirect AKI by enhancing calcineurin levels by inhibiting cytochrome P-450 isoenzymes.

4. Which one of the following answers is true?

A ACE inhibitors are forbidden in children with steroid-resistant nephrotic syndrome because of their risk of AKI.

B The concomitant use of NSAIDs and ACE inhibitors should be avoided.

C AKI caused by ACE inhibitors is always characterized by interstitial nephritis.

D Concomitant therapy with AT2-receptor antagonists enhances side effects of ACE inhibitors.

5. Which one of the following answers is not true?

A Nephrotoxicity is the most significant and limiting adverse effect caused by calcineurin inhibitors.

B The acute nephrotoxicity of CyA is a hemodynamically mediated phenomenon.

C A kidney biopsy is often necessary in renal transplant children to distinguish between CyA nephrotoxicity and rejection.
D CyA-induced HUS in BMT carries a rather good prognosis.

\section{References}

1. Coiffier B, Riouffol C (2007) Management of tumor lysis syndrome in adults. Expert Rev Anticancer Ther 7:233-239

2. Bertrand Y (2005) Recommendations of the French Society for the Control of Cancers and Leukemias in Children for the treatment of tumor lysis syndrome: results of a pediatric survey. Arch Pediatr 12(1):13-15

3. Davidson MB, Thakkar S, Hix JK, Bhandarkar ND, Wong A, Schreiber MJ (2004) Pathophysiology, clinical consequences, and treatment of tumor lysis syndrome. Am J Med 116:546554

4. Pui CH (2001) Urate oxidase in the prophylaxis or treatment of hyperuricemia: the United States experience. Semin Hematol 38:13-21

5. Renyi I, Bardi E, Udvardi E, Kovacs G, Bartyik K, Kajtar P, Masat P, Nagy K, Galantai I, Kiss C (2007) Prevention and treatment of hyperuricemia with rasburicase in children with leukemia and non-Hodgkin's lymphoma. Pathol Oncol Res 13:57-62

6. Goldman SC, Holcenberg JS, Finklestein JZ, Hutchinson R, Kreissman S, Johnson FL, Tou C, Harvey E, Morris E, Cairo MS (2001) A randomized comparison between rasburicase and allopurinol in children with lymphoma or leukemia at high risk for tumor lysis. Blood 97:2998-3003

7. Baeksgaard L, Sorensen JB (2003) Acute tumor lysis syndrome in solid tumors-a case report and review of the literature. Cancer Chemother Pharmacol 51:187-192

8. Filler G (2007) Calcineurin inhibitors in pediatric renal transplant recipients. Paediatr Drugs 9:165-174

9. Mehta RL, Chertow GM (2003) Acute renal failure definitions and classification: time for change? J Am Soc Nephrol 14:21782187

10. Bearman SI, Appelbaum FR, Buckner CD, Petersen FB, Fisher LD, Clift RA, Thomas ED (1988) Regimen-related toxicity in patients undergoing bone marrow transplantation. J Clin Oncol 6:1562-1568

11. Nolan CR, Anderson RJ (1998) Hospital-acquired acute renal failure. J Am Soc Nephrol 9:710-718

12. Liano F, Pascual J (1996) Epidemiology of acute renal failure: a prospective, multicenter, community-based study. Madrid Acute Renal Failure Study Group. Kidney Int 50:811-818

13. Groeneveld AB, Tran DD, van der MJ, Nauta JJ, Thijs LG (1991) Acute renal failure in the medical intensive care unit: predisposing, complicating factors and outcome. Nephron 59:602-610

14. de Mendonca A, Vincent JL, Suter PM, Moreno R, Dearden NM, Antonelli M, Takala J, Sprung C, Cantraine F (2000) Acute renal failure in the ICU: risk factors and outcome evaluated by the SOFA score. Intensive Care Med 26:915-921

15. Brivet FG, Kleinknecht DJ, Loirat P, Landais PJ (1996) Acute renal failure in intensive care units-causes, outcome, and prognostic factors of hospital mortality; a prospective, multicenter study. French Study Group on Acute Renal Failure. Crit Care Med 24:192-198

16. Wilkins RG, Faragher EB (1983) Acute renal failure in an intensive care unit: incidence, prediction and outcome. Anaesthesia 38:628-634 
17. Khan IH, Catto GR, Edward N, Macleod AM (1997) Acute renal failure: factors influencing nephrology referral and outcome. QJM 90:781-785

18. Feest TG, Round A, Hamad S (1993) Incidence of severe acute renal failure in adults: results of a community based study. BMJ 306:481-483

19. Rasmussen HH, Ibels LS (1982) Acute renal failure. Multivariate analysis of causes and risk factors. Am J Med 73:211-218

20. Hou SH, Bushinsky DA, Wish JB, Cohen JJ, Harrington JT (1983) Hospital-acquired renal insufficiency: a prospective study. Am J Med 74:243-248

21. Kleinknecht D, Pallot JL (1998) Epidemiology and prognosis of acute renal insufficiency in 1997. Recent data. Nephrologie 19:49-55

22. Kaufman J, Dhakal M, Patel B, Hamburger R (1991) Community-acquired acute renal failure. Am J Kidney Dis 17:191-198

23. Baraldi A, Ballestri M, Rapana R, Lucchi L, Borella P, Leonelli M, Furci L, Lusvarghi E (1998) Acute renal failure of medical type in an elderly population. Nephrol Dial Transplant 13(Suppl 7):25-29

24. deBroe ME, Porter GA, Bennett WM, Verpooten GA (2003) Clinical nephrotoxins: Renal injury from drugs and chemicals, 2 edn. Kluwer Academic, Dordrecht

25. Ronco C, Zanella M, Brendolan A, Milan M, Canato G, Zamperetti N, Bellomo R (2001) Management of severe acute renal failure in critically ill patients: an international survey in 345 centres. Nephrol Dial Transplant 16:230-237

26. Vijayan A, Miller SB (1998) Acute renal failure: prevention and nondialytic therapy. Semin Nephrol 18:523-532

27. Zager RA (1994) Acute renal failure in the setting of bone marrow transplantation. Kidney Int 46:1443-1458

28. Gruss E, Tomas JF, Bernis C, Rodriguez F, Traver JA, Fernandez RJ (1996) Nephroprotective effect of cilastatin in allogeneic bone marrow transplantation. Results from a retrospective analysis. Bone Marrow Transplant 18:761-765

29. Gruss E, Bernis C, Tomas JF, Garcia-Canton C, Figuera A, Mottellon JL, Paraiso V, Traver JA, Fernandez-Ranada JM (1995) Acute renal failure in patients following bone marrow transplantation: prevalence, risk factors and outcome. Am J Nephrol 15:473-479

30. Gruss E, Garciacanton C, Tomas JF, Bernis C, Figuera A, Berberana M, Paraiso V, Hernandezjaraz J, Fdzranada JM, Traver JA (1993) Risk factors for the development of acute renal failure during bone marrow transplantation. Kidney Int 44:1477

31. Parikh CR, McSweeney PA, Korular D, Ecder T, Merouani A, Taylor J, Slat-Vasquez V, Shpall EJ, Jones RB, Bearman SI, Schrier RW (2002) Renal dysfunction in allogeneic hematopoietic cell transplantation. Kidney Int 62:566-573

32. Herget-Rosenthal S, Uppenkamp M, Beelen D, Kohl D, Kribben A (2000) Renal complications of high-dose chemotherapy and peripheral blood stem cell transplantation. Nephron 84:136-141

33. Nevill TJ, Barnett MJ, Klingemann HG, Reece DE, Shepherd JD, Phillips GL (1991) Regimen-related toxicity of a busulfancyclophosphamide conditioning regimen in 70 patients undergoing allogeneic bone marrow transplantation. J Clin Oncol 9:1224-1232

34. Cowen D, Richaud P, Marit G, Cony-Makhoul P, Trouette R, Faberes C, Reiffers J (1992) Regimen-related toxicity in patients undergoing BMT with total body irradiation using a sweeping beam technique. Bone Marrow Transplant 10:515-519

35. Przepiorka D, Ippoliti C, Giralt S, van Beisen K, Mehra R, Deisseroth AB, Andersson B, Luna M, Cork A, Lee M (1994) A phase I-II study of high-dose thiotepa, busulfan and cyclophos- phamide as a preparative regimen for allogeneic marrow transplantation. Bone Marrow Transplant 14:449-453

36. Chan JC, Williams DM, Roth KS (2002) Kidney failure in infants and children. Pediatr Rev 23:47-60

37. Andreoli SP (2002) Acute renal failure. Curr Opin Pediatr 14:183-188

38. Hui-Stickle S, Brewer ED, Goldstein SL (2005) Pediatric ARF epidemiology at a tertiary care center from 1999 to 2001. Am J Kidney Dis 45:96-101

39. Moghal NE, Brocklebank JT, Meadow SR (1998) A review of acute renal failure in children: incidence, etiology and outcome. Clin Nephrol 49:91-95

40. Williams DM, Sreedhar SS, Mickell JJ, Chan JC (2002) Acute kidney failure: a pediatric experience over 20 years. Arch Pediatr Adolesc Med 156:893-900

41. Stapleton FB, Jones DP, Green RS (1987) Acute renal failure in neonates: incidence, etiology and outcome. Pediatr Nephrol $1: 314-320$

42. Gouyon JB, Guignard JP (2000) Management of acute renal failure in newborns. Pediatr Nephrol 14:1037-1044

43. Mehta KP (1991) Neonatal renal failure. Indian Pediatr 28:7-9

44. Toth-Heyn P, Drukker A, Guignard JP (2000) The stressed neonatal kidney: from pathophysiology to clinical management of neonatal vasomotor nephropathy. Pediatr Nephrol 14:227239

45. Bailey D, Phan V, Litalien C, Ducruet T, Merouani A, Lacroix J, Gauvin F (2007) Risk factors of acute renal failure in critically ill children: A prospective descriptive epidemiological study. Pediatr Crit Care Med 8:29-35

46. Medina VA, Lopez-Herce CJ, Lopez FY, Anton GM, Concha TA, Rey GC, Santos RF (2004) Acute renal failure in criticallyill children. A preliminary study. An Pediatr (Barc) 61:509514

47. Kentouche K (1999) Akute Niereninsuffizienz innerhalb der ersten 30 Tage nach Knochenmarktransplantation bei Kindern. Friedrich-Schiller-University, Jena

48. Van Why SK, Friedman AL, Wei LJ, Hong R (1991) Renal insufficiency after bone marrow transplantation in children. Bone Marrow Transplant 7:383-388

49. Kist-van Holthe JE, van Zwet JM, Brand R, van Weel MH, Vossen JM, van der Heijden AJ (1998) Bone marrow transplantation in children: consequences for renal function shortly after and 1 year post-BMT. Bone Marrow Transplant 22:559-564

50. Balduzzi A, Valsecchi MG, Silvestri D, Locatelli F, Manfredini L, Busca A, Iori AP, Messina C, Prete A, Andolina M, Porta F, Favre C, Ceppi S, Giorgiani G, Lanino E, Rovelli A, Fagioli F, De Fusco C, Rondelli R, Uderzo C (2002) Transplant-related toxicity and mortality: an AIEOP prospective study in 636 pediatric patients transplanted for acute leukemia. Bone Marrow Transplant 29:93-100

51. Litalien C, Jacqz-Aigrain E (2001) Risks and benefits of nonsteroidal anti-inflammatory drugs in children: a comparison with paracetamol. Paediatr Drugs 3:817-858

52. John CM, Shukla R, Jones CA (2007) Using NSAID in volume depleted children can precipitate acute renal failure. Arch Dis Child 92:524-526

53. Moghal NE, Hegde S, Eastham KM (2004) Ibuprofen and acute renal failure in a toddler. Arch Dis Child 89:276-277

54. Ulinski T, Guigonis V, Dunan O, Bensman A (2004) Acute renal failure after treatment with non-steroidal anti-inflammatory drugs. Eur J Pediatr 163:148-150

55. Krause I, Cleper R, Eisenstein B, Davidovits M (2005) Acute renal failure, associated with non-steroidal anti-inflammatory drugs in healthy children. Pediatr Nephrol 20:1295-1298 
56. Kallanagowdar C, LeBreton A, Aviles DH (2006) Acute renal failure. Clin Pediatr 45:771-773

57. Fletcher JT, Graf N, Scarman A, Saleh H, Alexander SI (2006) Nephrotoxicity with cyclooxygenase 2 inhibitor use in children. Pediatr Nephrol 21:1893-1897

58. Chan FK, Hung LC, Suen BY, Wu JC, Lee KC, Leung VK, Hui AJ, To KF, Leung WK, Wong VW, Chung SC, Sung JJ (2002) Celecoxib versus diclofenac and omeprazole in reducing the risk of recurrent ulcer bleeding in patients with arthritis. N Engl J Med 347:2104-2110

59. Cheng HF, Harris RC (2005) Renal effects of non-steroidal antiinflammatory drugs and selective cyclooxygenase-2 inhibitors. Curr Pharm Des 11:1795-1804

60. Shah SS, Ohlsson A (2006) Ibuprofen for the prevention of patent ductus arteriosus in preterm and/or low birth weight infants. Cochrane Database Syst Rev CD004213

61. Ohlsson A, Walia R, Shah S (2005) Ibuprofen for the treatment of patent ductus arteriosus in preterm and/or low birth weight infants. Cochrane Database Syst Rev CD003481

62. Herrera C, Holberton J, Davis P (2007) Prolonged versus short course of indomethacin for the treatment of patent ductus arteriosus in preterm infants. Cochrane Database Syst Rev CD003480

63. Cuzzolin L, Dal Cere M, Fanos V (2001) NSAID-induced nephrotoxicity from the fetus to the child. Drug Saf 24:9-18

64. Benini D, Fanos V, Cuzzolin L, Tato L (2004) In utero exposure to nonsteroidal anti-inflammatory drugs: neonatal renal failure. Pediatr Nephrol 19:232-234

65. Van Biervliet S, Raes A, Vande WJ, Van Winckel M, Robberecht E, Praet M (2006) Mesalazine interstitial nephritis presenting as colitis ulcerosa exacerbation. Acta Gastroenterol Belg 69:321-322

66. Dillon JJ (2001) Nephrotoxicity from antibacterial, antifungal, and antiviral drugs. In: Molitoris BA, Finn WF (eds) Acute renal failure: a companion to Brenner and Rector's the kidney. WB Saunders, Philadelphia, pp 349-364

67. Martinez-Salgado C, Lopez-Hernandez FJ, Lopez-Novoa JM (2007) Glomerular nephrotoxicity of aminoglycosides. Toxicol Appl Pharmacol 223:86-98

68. Smith CR, Baughman KL, Edwards CQ, Rogers JF, Lietman PS (1977) Controlled comparison of amikacin and gentamicin. N Engl J Med 296:349-353

69. Paterson DL, Robson JM, Wagener MM (1998) Risk factors for toxicity in elderly patients given aminoglycosides once daily. J Gen Intern Med 13:735-739

70. Smith CR, Moore RD, Lietman PS (1986) Studies of risk factors for aminoglycoside nephrotoxicity. Am J Kidney Dis 8:308-313

71. Moore RD, Smith CR, Lipsky JJ, Mellits ED, Lietman PS (1984) Risk factors for nephrotoxicity in patients treated with aminoglycosides. Ann Intern Med 100:352-357

72. Chesney RW, Jones DP (2004) Nephrotoxins. In: Avner ED, Harmon WE, Niaudet P (eds) Pediatric nephrology, 5th edn. Lippincott Williams and Wilkins, Philadelphia, pp 987-1004

73. Uijtendaal EV, Rademaker CM, Schobben AF, Fleer A, Kramer WL, van Vught AJ, Kimpen JL, van Dijk A (2001) Once-daily versus multiple-daily gentamicin in infants and children. Ther Drug Monit 23:506-513

74. Smyth AR, Tan KH (2006) Once-daily versus multiple-daily dosing with intravenous aminoglycosides for cystic fibrosis. Cochrane Database Syst Rev 3:CD002009

75. Verpooten GA, Tulkens PM, Molitoris BA (2003) Aminoglycosides and vancomycin. In: deBroe ME, Porter GA, Bennett WM, Verpooten GA (eds) Clinical nephrotoxins, 2nd edn. Kluwer Academic, Dordrecht, pp 151-170

76. Rao SC, Ahmed M, Hagan R (2006) One dose per day compared to multiple doses per day of gentamicin for treatment of suspected or proven sepsis in neonates. Cochrane Database Syst Rev CD005091

77. Tune BM (1997) Nephrotoxicity of beta-lactam antibiotics: mechanisms and strategies for prevention. Pediatr Nephrol 11:768-772

78. Fanos V, Cataldi L (1999) Antibacterial-induced nephrotoxicity in the newborn. Drug Saf 20:245-267

79. Tong JE, Howell DN, Foreman JW (2007) Drug-induced granulomatous interstitial nephritis in a pediatric patient. Pediatr Nephrol 22:306-309

80. Mohkam M, Karimi A, Gharib A, Daneshmand H, Khatami A, Ghojevand N, Sharifian M (2007) Ceftriaxone associated nephrolithiasis: a prospective study in 284 children. Pediatr Nephrol 22:690-694

81. Avci Z, Koktener A, Uras N, Catal F, Karadag A, Tekin O, Degirmencioglu H, Baskin E (2004) Nephrolithiasis associated with ceftriaxone therapy: a prospective study in 51 children. Arch Dis Child 89:1069-1072

82. Kapur G, Valentini RP, Mattoo TK, Warrier I, Imam AA (2008) Ceftriaxone induced hemolysis complicated by acute renal failure. Pediatr Blood Cancer 50:139-142

83. Cataldi L, Leone R, Moretti U, De Mitri B, Fanos V, Ruggeri L, Sabatino G, Torcasio F, Zanardo V, Attardo G, Riccobene F, Martano C, Benini D, Cuzzolin L (2005) Potential risk factors for the development of acute renal failure in preterm newborn infants: a case-control study. Arch Dis Child Fetal Neonatal Ed 90:F514-F519

84. Fanos V, Mussap M, Verlato G, Plebani M, Padovani EM (1996) Evaluation of antibiotic-induced nephrotoxicity in preterm neonates by determining urinary alpha 1-microglobulin. Pediatr Nephrol 10:645-647

85. Cojocel C (2003) Beta-lactam antibiotics. In: deBroe ME, Porter GA, Bennett WM, Verpooten GA (eds) Clinical nephrotoxins, 2nd edn. Kluwer Academic, Dordrecht, pp 171-198

86. Watkins VS, Polk RE, Stotka JL (1997) Drug interactions of macrolides: emphasis on dirithromycin. Ann Pharmacother 31:349-356

87. Vaamonde CA, Contreras GN, Diego JM (2003) Sulfonamides, sulfadiazine, trimethoprim-sulfamethoxazole, pentamidine, pyrimethamine, dapsone, quinolones. In: deBroe ME, Porter GA, Bennett WM, Verpooten GA (eds) Clinical nephrotoxins, 2nd edn. Kluwer Academic, Dordrecht, pp 223-247

88. Goldman RD, Koren G (2004) Amphotericin B nephrotoxicity in children. J Pediatr Hematol Oncol 26:421-426

89. Koren G, Chen N, Aleksa K (2007) Drug-induced nephrotoxicity in children: pharmacologically based prevention of long-term impairment. Paediatr Drugs 9:139-142

90. Fanos V, Cataldi L (2000) Amphotericin B-induced nephrotoxicity: a review. J Chemother 12:463-470

91. Pathak A, Pien FD, Carvalho L (1998) Amphotericin B use in a community hospital, with special emphasis on side effects. Clin Infect Dis 26:334-338

92. Clements JS Jr, Peacock JE Jr (1990) Amphotericin B revisited: reassessment of toxicity. Am J Med 88:22N-27N

93. Luber AD, Maa L, Lam M, Guglielmo BJ (1999) Risk factors for amphotericin B-induced nephrotoxicity. J Antimicrob Chemother 43:267-271

94. Stein RS, Albridge K, Lenox RK, Ray W, Flexner JM (1988) Nephrotoxicity in leukemic patients receiving empirical amphotericin B and aminoglycosides. South Med J 81:1095-1099

95. Harbarth S, Pestotnik SL, Lloyd JF, Burke JP, Samore MH (2001) The epidemiology of nephrotoxicity associated with conventional amphotericin B therapy. Am J Med 111:528-534

96. Bates DW, Su L, Yu DT, Chertow GM, Seger DL, Gomes DR, Platt R (2001) Correlates of acute renal failure in patients receiving parenteral amphotericin B. Kidney Int 60:14521459 
97. Costa S, Nucci M (2001) Can we decrease amphotericin nephrotoxicity? Curr Opin Crit Care 7:379-383

98. Lalezari JP, Stagg RJ, Kuppermann BD, Holland GN, Kramer F, Ives DV, Youle M, Robinson MR, Drew WL, Jaffe HS (1997) Intravenous cidofovir for peripheral cytomegalovirus retinitis in patients with AIDS. A randomized, controlled trial. Ann Intern Med 126:257-263

99. Izzedine H, Launay-Vacher V, Deray G (2005) Antiviral druginduced nephrotoxicity. Am J Kidney Dis 45:804-817

100. Berns JS, Cohen RM, Rudnick MR (2003) Antiviral agents. In: deBroe ME, Porter GA, Bennett WM, Verpooten GA (eds) Clinical nephrotoxins, 2nd edn. Kluwer Academic, Dordrecht, pp 249-262

101. Pacheco LR, Tavares HM, Moyses NM, Dantas M, Rocha LS, Ribeiro KM, Figueiredo JF (2005) Acute renal failure related to intravenous acyclovir. Rev Assoc Med Bras 51:275-278

102. Vomiero G, Carpenter B, Robb I, Filler G (2002) Combination of ceftriaxone and acyclovir - an underestimated nephrotoxic potential? Pediatr Nephrol 17:633-637

103. Deray G, Martinez F, Katlama C, Levaltier B, Beaufils H, Danis M, Rozenheim M, Baumelou A, Dohin E, Gentilini M (1989) Foscarnet nephrotoxicity: mechanism, incidence and prevention. Am J Nephrol 9:316-321

104. Cacoub P, Deray G, Baumelou A, Le Hoang P, Rozenbaum W, Gentilini M, Soubrie C, Rousselie R, Jacobs C (1988) Acute renal failure induced by foscarnet: 4 cases. Clin Nephrol 29:315-318

105. Jacobson MA (1992) Review of the toxicities of foscarnet. J Acquir Immune Defic Syndr 5(Suppl 1):S11-S17

106. Chatelain E, Deminiere C, Lacut JY, Potaux L (1998) Severe renal failure and polyneuritis induced by foscarnet. Nephrol Dial Transplant 13:2368-2369

107. Deray G, Katlama C, Dohin E (1990) Prevention of foscarnet nephrotoxicity. Ann Intern Med 113:332

108. Reusser P, Einsele H, Lee J, Volin L, Rovira M, Engelhard D, Finke J, Cordonnier C, Link H, Ljungman P (2002) Randomized multicenter trial of foscarnet versus ganciclovir for preemptive therapy of cytomegalovirus infection after allogeneic stem cell transplantation. Blood 99:1159-1164

109. Coppo R, Peruzzi L, Amore A, Piccoli A, Cochat P, Stone R, Kirschstein M, Linne T (2007) IgACE: A placebo-controlled, randomized trial of angiotensin-converting enzyme inhibitors in children and young people with IgA nephropathy and moderate proteinuria. J Am Soc Nephrol 18:1880-1888

110. Mattoo TK (2007) Medical management of vesicoureteral reflux. Pediatr Nephrol 22:1113-1120

111. Hogg RJ, Delucchi A, Sakihara G, Wells TG, Tenney F, Batisky DL, Blumer JL, Vogt BA, Lo MW, Hand E, Panebianco D, Rippley R, Shaw W, Shahinfar S (2007) A multicenter study of the pharmacokinetics of lisinopril in pediatric patients with hypertension. Pediatr Nephrol 22:695-701

112. Momma K (2006) ACE inhibitors in pediatric patients with heart failure. Paediatr Drugs 8:55-69

113. Robinson RF, Nahata MC, Batisky DL, Mahan JD (2005) Pharmacologic treatment of chronic pediatric hypertension. Paediatr Drugs 7:27-40

114. Hilgers KF, Dotsch J, Rascher W, Mann JF (2004) Treatment strategies in patients with chronic renal disease: ACE inhibitors, angiotensin receptor antagonists, or both? Pediatr Nephrol 19:956-961

115. Wuhl E, Mehls O, Schaefer F (2004) Antihypertensive and antiproteinuric efficacy of ramipril in children with chronic renal failure. Kidney Int 66:768-776

116. Olowu WA, Adenowo OA, Elusiyan JB (2006) Reversible renal failure in hypertensive idiopathic nephrotics treated with captopril. Saudi J Kidney Dis Transplant 17:216-221
117. Hanevold CD (2006) Acute renal failure during lisinopril and losartan therapy for proteinuria. Pharmacotherapy 26:1348-1351

118. Remuzzi G, Ruggenenti P (2006) Overview of randomised trials of ACE inhibitors. Lancet 368:555-556

119. de Jong PE (2003) Angiotensin I converting enzyme inhibitors and angiotensin II receptor antagonists. In: deBroe ME, Porter GA, Bennett WM, Verpooten GA (eds) Clinical nephrotoxins, 2nd edn. Kluwer Academic, Dordrecht, pp 325-338

120. Krishna EV, Mehta AV, Subrahmanyam AB, Wattad AA (1996) Acute renal failure associated with use of angiotensin converting enzyme inhibitor-a report of two children with Down syndrome. J Tenn Med Assoc 89:5-7

121. Ahmad T, Coulthard MG, Eastham EJ (1989) Reversible renal failure due to the use of captopril in a renal allograft recipient treated with cyclosporin. Nephrol Dial Transplant 4:311-312

122. Wiggelinkhuizen J (1987) Reversible renal failure and captopril therapy in renovascular hypertension. S Afr Med J 71:332-333

123. Burdmann AA, Yu L, Andoh TF, Perico N, Bennett WM (2003) Calcineurin inhibitors and sirolimus. In: deBroe ME, Porter GA, Bennett WM, Verpooten GA (eds) Clinical nephrotoxins, 2nd edn. Kluwer Academic, Dordrecht, pp 403-458

124. Lee DB (1997) Cyclosporine and the renin-angiotensin axis. Kidney Int 52:248-260

125. de Mattos AM, Olyaei AJ, Bennett WM (2000) Nephrotoxicity of immunosuppressive drugs: long-term consequences and challenges for the future. Am J Kidney Dis 35:333-346

126. Fisher NC, Malag M, Gonzlez-Pinto I (2000) The clinical impact of nephrotoxicity in liver transplantation. Transplantation 69: SS18-SS22

127. Parry G, Meiser B, Rabago G (2000) The clinical impact of cyclosporine nephrotoxicity in heart transplantation. Transplantation 69:SS23-SS26

128. Tsimaratos M, Viard L, Kreitmann B, Remediani C, Picon G, Camboulives J, Sarles J, Metras D (2000) Kidney function in cyclosporine-treated paediatric pulmonary transplant recipients. Transplantation 69:2055-2059

129. Noel C, Hazzan M, Noel-Walter MP, Jouet JP (1998) Renal failure and bone marrow transplantation. Nephrol Dial Transplant 13:2464-2466

130. Olyaei AJ, de Mattos AM, Bennett WM (2001) Nephrotoxicity of immunosuppressive drugs: new insight and preventive strategies. Curr Opin Crit Care 7:384-389

131. Murphy SW, Barrett BJ, Parfrey PS (2000) Contrast nephropathy. J Am Soc Nephrol 11:177-182

132. Rudnick MR, Goldfarb S, Wexler L, Ludbrook PA, Murphy MJ, Halpern EF, Hill JA, Winniford M, Cohen MB, VanFossen DB (1995) Nephrotoxicity of ionic and nonionic contrast media in 1196 patients: a randomized trial. The Iohexol Cooperative Study. Kidney Int 47:254-261

133. Barrett BJ, Carlisle EJ (1993) Metaanalysis of the relative nephrotoxicity of high- and low-osmolality iodinated contrast media. Radiology 188:171-178

134. Tepel M, Zidek W (2004) N-Acetylcysteine in nephrology; contrast nephropathy and beyond. Curr Opin Nephrol Hypertens 13:649-654

135. Tepel M, Zidek W (2002) Acetylcysteine and contrast media nephropathy. Curr Opin Nephrol Hypertens 11:503-506

136. Tepel M, Zidek W (2001) Acetylcysteine for radiocontrast nephropathy. Curr Opin Crit Care 7:390-392

137. Rudnick MR, Kesselheim A, Goldfarb S (2006) Contrastinduced nephropathy: how it develops, how to prevent it. Cleve Clin J Med 73:75-77

138. Patzer L, Kentouche K, Ringelmann F, Misselwitz J (2003) Renal function following hematological stem cell transplantation in childhood. Pediatr Nephrol 18:623-635 
139. Stohr W, Paulides M, Bielack S, Jurgens H, Treuner J, Rossi R, Langer T, Beck JD (2007) Ifosfamide-induced nephrotoxicity in 593 sarcoma patients: a report from the Late Effects Surveillance System. Pediatr Blood Cancer 48:447-452

140. Rossi R, Kleta R, Ehrich JH (1999) Renal involvement in children with malignancies. Pediatr Nephrol 13:153-162

141. Skinner R, Cotterill SJ, Stevens MC (2000) Risk factors for nephrotoxicity after ifosfamide treatment in children: a UKCCSG Late Effects Group study. United Kingdom Children's Cancer Study Group. Br J Cancer 82:1636-1645

142. Skinner R, Pearson AD, English MW, Price L, Wyllie RA, Coulthard MG, Craft AW (1998) Cisplatin dose rate as a risk factor for nephrotoxicity in children. Br J Cancer 77:1677-1682

143. Schrier RW (2002) Cancer therapy and renal injury. J Clin Invest 110:743-745

144. Kintzel PE (2001) Anticancer drug-induced kidney disorders. Drug Saf 24:19-38

145. Darmon M, Ciroldi M, Thiery G, Schlemmer B, Azoulay E (2006) Clinical review: specific aspects of acute renal failure in cancer patients. Crit Care 10:211

146. Rossi R, Pleyer J, Schafers P, Kuhn N, Kleta R, Deufel T, Jurgens H (1999) Development of ifosfamide-induced nephrotoxicity: prospective follow-up in 75 patients. Med Pediatr Oncol 32:177-182

147. Rossi R, Godde A, Kleinebrand A, Riepenhausen M, Boos J, Ritter J, Jurgens H (1994) Unilateral nephrectomy and cisplatin as risk factors of ifosfamide-induced nephrotoxicity: analysis of 120 patients. J Clin Oncol 12:159-165

148. Stuart-Harris RC, Harper PG, Parsons CA, Kaye SB, Mooney CA, Gowing NF, Wiltshaw E (1983) High-dose alkylation therapy using ifosfamide infusion with mesna in the treatment of adult advanced soft-tissue sarcoma. Cancer Chemother Pharmacol 11:69-72

149. Willemse PH, de Jong PE, Elema JD, Mulder NH (1989) Severe renal failure following high-dose ifosfamide and mesna. Cancer Chemother Pharmacol 23:329-330

150. Patzer L, Ringelmann F, Kentouche K, Zintl F, Misselwitz J (1999) Ungewöhnlicher Verlauf eines deToni-Debrè-FanconiSyndroms nach Ifosfamidtherapie. Pädiatrie und Grenzgebiete 38:173-183

151. Safirstein R, Winston J, Moel D, Dikman S, Guttenplan J (1987) Cisplatin nephrotoxicity: insights into mechanism. Int J Androl 10:325-346

152. Ramesh G, Reeves WB (2004) Inflammatory cytokines in acute renal failure. Kidney Int Suppl 66:S56-S61

153. Sheikh-Hamad D, Cacini W, Buckley AR, Isaac J, Truong LD, Tsao CC, Kishore BK (2004) Cellular and molecular studies on cisplatin-induced apoptotic cell death in rat kidney. Arch Toxicol 78:147-155

154. Goldstein RS, Mayor GH (1983) Minireview. The nephrotoxicity of cisplatin. Life Sci 32:685-690

155. Womer RB, Pritchard J, Barratt TM (1985) Renal toxicity of cisplatin in children. J Pediatr 106:659-663

156. Isnard-Bagnis C, Deray G (2003) Anticancer drugs. In: deBroe ME, Porter GA, Bennett WM, Verpooten GA (eds) Clinical nephrotoxins, 2nd edn. Kluwer Academic, Dordrecht, pp 353372

157. Al Sarraf M, Fletcher W, Oishi N, Pugh R, Hewlett JS, Balducci L, McCracken J, Padilla F (1982) Cisplatin hydration with and without mannitol diuresis in refractory disseminated malignant melanoma: a Southwest Oncology Group study. Cancer Treat Rep 66:31-35

158. Stathopoulos GP, Boulikas T, Vougiouka M, Deliconstantinos G, Rigatos S, Darli E, Viliotou V, Stathopoulos JG (2005) Pharmacokinetics and adverse reactions of a new liposomal cisplatin (Lipoplatin): phase I study. Oncol Rep 13:589-595
159. Devarajan P, Tarabishi R, Mishra J, Ma Q, Kourvetaris A, Vougiouka M, Boulikas T (2004) Low renal toxicity of lipoplatin compared to cisplatin in animals. Anticancer Res 24:2193-2200

160. Widemann BC, Adamson PC (2006) Understanding and managing methotrexate nephrotoxicity. Oncologist 11:694-703

161. Hingorani SR, Guthrie K, Batchelder A, Schoch G, Aboulhosn N, Manchion J, McDonald GB (2005) Acute renal failure after myeloablative hematopoietic cell transplant: incidence and risk factors. Kidney Int 67:272-277

162. Zager RA, Johnson AC, Lund S, Hanson S (2006) Acute renal failure: determinants and characteristics of the injury-induced hyperinflammatory response. Am J Physiol Renal Physiol 291: F546-F556

163. Markowitz GS, Fine PL, Stack JI, Kunis CL, Radhakrishnan J, Palecki W, Park J, Nasr SH, Hoh S, Siegel DS, D'Agati VD (2003) Toxic acute tubular necrosis following treatment with zoledronate (Zometa). Kidney Int 64:281-289

164. Thornton J, Ashcroft DM, Mughal MZ, Elliott RA, O’Neill TW, Symmons D (2006) Systematic review of effectiveness of bisphosphonates in treatment of low bone mineral density and fragility fractures in juvenile idiopathic arthritis. Arch Dis Child 91:753-761

165. Tufan F, Kamali S, Erer B, Gul A, Inanc M, Ocal L, Konice M, Aral O (2007) Safety of high-dose intravenous immunoglobulin in systemic autoimmune diseases. Clin Rheumatol 11:19131915

166. Katz U, Achiron A, Sherer Y, Shoenfeld Y (2007) Safety of intravenous immunoglobulin (IVIG) therapy. Autoimmun Rev 6:257-259

167. Daphnis E, Stylianou K, Alexandrakis M, Xylouri I, Vardaki E, Stratigis S, Kyriazis J (2007) Acute renal failure, translocational hyponatremia and hyperkalemia following intravenous immunoglobulin therapy. Nephron Clin Pract 106:c143-c148

168. Subtirelu MM, Flynn JT, Schechner RS, Pullman JM, Feuerstein D, Del Rio M (2005) Acute renal failure in a pediatric kidney allograft recipient treated with intravenous immunoglobulin for parvovirus B19 induced pure red cell aplasia. Pediatr Transplant 9:801-804

169. Swanepoel C, Naicker S, Moosa R, Katz I, Suleiman SM, Twahir M (2003) nephrotoxins in Africa. In: deBroe ME, Porter GA, Bennett WM, Verpooten GA (eds) Clinical nephrotoxins, 2nd edn. Kluwer Academic, Dordrecht, pp 603-611

170. Seedat YK (1978) Acute renal failure among Blacks and Indians in South Africa. S Afr Med J 54:427-431

171. Knochel JP (2001) Nontraumatic rhabdomyolysis. In: Molitoris BA, Finn WF (eds) Acute renal failure: a companion to Brenner and Rector's the kidney. WB Saunders, Philadelphia, pp 220 226

172. Kellum JA, Decker M (2001) Use of dopamine in acute renal failure: a meta-analysis. Crit Care Med 29:1526-1531

173. Abay MC, Reyes JD, Everts K, Wisser J (2007) Current literature questions the routine use of low-dose dopamine. AANA J 75:57-63

174. Schenarts PJ, Sagraves SG, Bard MR, Toschlog EA, Goettler CE, Newell MA, Rotondo MF (2006) Low-dose dopamine: a physiologically based review. Curr Surg 63:219-225

175. Leclerc F, Sadik A (2007) Is there still a place for dopamine in the paediatric critical care setting? Ann Fr Anesth Reanim 26:576-580

176. Barrington K, Brion LP (2002) Dopamine versus no treatment to prevent renal dysfunction in indomethacin-treated preterm newborn infants. Cochrane Database Syst Rev CD003213

177. Kellum JA (1997) The use of diuretics and dopamine in acute renal failure: a systematic review of the evidence. Crit Care 1:53-59

178. Asif A, Epstein M (2004) Prevention of radiocontrast-induced nephropathy. Am J Kidney Dis 44:12-24 
179. Barletta GM, Bunchman TE (2004) Acute renal failure in children and infants. Curr Opin Crit Care 10:499-504

180. Quan A, Quigley R (2005) Renal replacement therapy and acute renal failure. Curr Opin Pediatr 17:205-209

181. Bock KR (2005) Renal replacement therapy in pediatric critical care medicine. Curr Opin Pediatr 17:368-371

182. Flynn JT, Kershaw DB, Smoyer WE, Brophy PD, McBryde KD, Bunchman TE (2001) Peritoneal dialysis for management of pediatric acute renal failure. Perit Dial Int 21:390-394

183. Maxvold NJ, Smoyer WE, Gardner JJ, Bunchman TE (1997) Management of acute renal failure in the pediatric patient: hemofiltration versus hemodialysis. Am J Kidney Dis 30:S84-S88

184. Strazdins V, Watson AR, Harvey B (2004) Renal replacement therapy for acute renal failure in children: European guidelines. Pediatr Nephrol 19:199-207

185. Askenazi DJ, Feig DI, Graham NM, Hui-Stickle S, Goldstein SL (2006) 3-5 year longitudinal follow-up of pediatric patients after acute renal failure. Kidney Int 69:184-189

186. Henrich WL (2005) Nephrotoxicity of several newer agents. Kidney Int Suppl 94:S107-S109

187. Grunfeld JP, Kleinknecht D, Droz D (1993) Acute interstitial nephritis. In: Schrier RW, Gottschalk CW (eds) Diseases of the kidney, 5th edn. Little Brown, Boston, pp 1331-1353

188. Zager RA, O'Quigley J, Zager BK, Alpers CE, Shulman HM, Gamelin LM, Stewart P, Thomas ED (1989) Acute renal failure following bone marrow transplantation: a retrospective study of 272 patients. Am J Kidney Dis 13:210-216

189. Lane PH, Mauer SM, Blazar BR, Ramsay NK, Kashtan CE (1994) Outcome of dialysis for acute renal failure in pediatric bone marrow transplant patients. Bone Marrow Transplant 13:613-617

190. Patzer L, Ringelmann F, Kentouche K, Fuchs D, Zintl F, Brandis M, Zimmerhackl LB, Misselwitz J (2001) Renal function in long-term survivors of stem cell transplantation in childhood. A prospective trial. Bone Marrow Transplant 27:319-327

191. Kist-van Holthe JE, Bresters D, Ahmed-Ousenkova YM, Goedvolk CA, Abbink FC, Wolterbeek R, Bredius RG, Pauwels EK, van der Heijden AJ (2005) Long-term renal function after hemopoietic stem cell transplantation in children. Bone Marrow Transplant 36:605-610

\section{Answers:}
1. A
2. A
3. B
4. B
5. D 